\title{
Research on Non-university Tertiary Mathematics
}

\author{
Claire Wladis, John Smith and Irene Duranczyk
}

\section{Description of Activities and Presentations}

This session focused on research being conducted at non-university tertiary institutions. Instructors in adult education as well as other non-university postsecondary institutions participated. The participants of the session shared concerns about wanting to know more about the non-university mathematics classroom through classroom-based research by practitioners. Examples of research presently being conducted were shared (Mesa, Wladis, \& Watkins, 2014; Sitomer et al., 2012; Wladis, Conway, \& Hachey, 2016) and are cited below. The goal for developing collaborative research and/or grant proposals among researchers of similar interest continues.

A presentation of the National Science Foundation grant Algebra instruction at community colleges: An exploration of its relationship with student success (Watkins, Strom, Mesa, Kohli, \& Duranczyk, 2015) design was shared. The researchers are exploring the impact of students' and instructors' pre-existing and moderating variable on the relationship between student-instructor interaction with mathematics in the classroom and students' performance outcomes. Research on how individual and institutional characteristics factor into failure rates and performance measures exists, but there is little information about the fundamental work of teachers in the classroom, and the interaction that occur between instructors, students, and the mathematical content. A qualitative study (Smith, 2016), provided the student point of view. It explored students' reflections on their experiences (unsuccessful and successful) in mathematics at the community college. Student voices provided essential insights as to how postsecondary educators might foster positive learning transformations, and avoid being the source of needless obstacles to degree attainment. Then the City University of New York

\footnotetext{
C. Wladis $(\bowtie)$

City University of New York, New York, USA

e-mail: cwladis@gmail.com

(C) The Author(s) 2017

G. Kaiser (ed.), Proceedings of the 13th International Congress on Mathematical

Education, ICME-13 Monographs, DOI 10.1007/978-3-319-62597-3_110
} 
(CUNY) was presented as an example of a college system in the United States where research by community college faculty has been systematically supported, and the structures to support faculty research were described. A few examples of research projects coming out of this CUNY system were presented: An NSF-funded project exploring factors that predict which characteristics put students at higher risk of dropping out of online versus face-to-face STEM courses (Wladis, Conway, \& Hachey, 2014); and a project, instigated by elementary algebra instructors, to create a concept inventory for elementary algebra at the tertiary level.

\section{References}

Mesa, V., Wladis, C., \& Watkins, L. (2014). Research problems in community college mathematics education: Testing the boundaries of $\mathrm{K}-12$ research. Journal for Research in Mathematics Education, 45(2), 173-192.

Sitomer, A., Strom, A., Mesa, V., Duranczyk, I. M., Nabb, K., Smith, J., et al. (2012). Moving from anecdote to evidence: A proposed research agenda in community college mathematics education. MathAMATYC Educator, 4(1), 35-40.

Smith, J. T. (2016). Stories of success: A phenomenological study of positive transformative learning experiences of low-socioeconomic status community college mathematics students (Doctoral dissertation, Knoxville, TN: The University of Tennessee).

Watkins, L., Strom, A., Mesa, V., Kohli, N., \& Duranczyk, I. (2015). Algebra instruction at community colleges: An exploration of its relationship with student success, National Science Foundation Award \# 1561436.

Wladis, C., Conway, K. M., \& Hachey, A. C. (2014). Can student characteristics be used to effectively identify students at-risk in the online STEM environment?, National Science Foundation Award \#1431649.

Wladis, C., Conway, K. M., \& Hachey, A. C. (2016). Assessing readiness for online educationresearch models for identifying students at risk. Online Learning [Special Section: Best Papers Presented at the OLC 21st International Conference on Online Learning and Innovate 2016], 20(3), 97-109.

Open Access Except where otherwise noted, this chapter is licensed under a Creative Commons Attribution 4.0 International License. To view a copy of this license, visit http://creativecommons. org/licenses/by/4.0/.

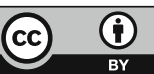

